\title{
MACROCRYSTAL PHLOGOPITE RB-SR DATES FOR THE EKATI PROPERTY KIMBERLITES, SLAVE PROVINCE, CANADA: EVIDENCE FOR MULTIPLE INTRUSIVE EPISODES IN THE PALEOCENE AND EOCENE
}

\author{
Robert Creaser ${ }^{1}$, Herman Grütter ${ }^{2}$, Jon Carlson and Barbara Crawford ${ }^{\mathbf{3}}$ \\ ${ }^{1}$ University of Alberta, Canada; ${ }^{2}$ Mineral Services Canada $;{ }^{3}$ BHP Billiton Diamonds, Canada.
}

\section{INTRODUCTION}

Kimberlites from the Slave Province, Canada, are now known to span a large age range from Cambrian to Eocene time (Heaman et al, 2003). A broad regional clustering of age distributions is also evident, with Lower Paleozoic ages characteristic of kimberlites from the western and southern Slave Province, and Upper Paleozoic to Mesozoic ages from the northern and northeastern Slave Province. From the central Slave Province in the Lac De Gras area, Cretaceous and Tertiary ages are more typical. Here, we report the results of a detailed age dating study of kimberlites from the Ekati property, using the $\mathrm{Rb}-\mathrm{Sr}$ method on macrocrystal kimberlitic phlogopite. The $\mathrm{Rb}-\mathrm{Sr}$ dates obtained are consistent with independent methods of dating, such as palynoflora analysis, and indicate that kimberlite emplacement took place over a period of 16 million years during Paleocene and Eocene time. At present, three distinct episodes of kimberlite emplacement are recognized at $\sim 47 \mathrm{Ma}, \sim 51-55 \mathrm{Ma}$, $\sim 58-61 \mathrm{Ma}$.

\section{METHODS}

Samples of visible phlogopite were removed from kimberlite without crushing the entire rock, a process that typically liberates any xenocrystal mica. All grains were chosen for $\mathrm{Rb}-\mathrm{Sr}$ analysis after careful inspection and cleaning under a binocular microscope to eliminate altered grains, adhering kimberlitic matrix and chloritized rims. Samples were then leached in dilute acid in an ultrasonic bath to remove trace carbonate minerals, prior to repeated rinses in ultrapure water. The leach-cleaned mica grains were spiked with a mixed ${ }^{84} \mathrm{Sr}^{87} \mathrm{Rb}$ spike to enable isotope dilution analysis and dissolved in a $\mathrm{HF}: \mathrm{HNO}_{3}$. Strontium and $\mathrm{Rb}$ were separated by standard cation-exchange chromatographic methods. Isotopic analysis was performed using Thermal Ionization Mass Spectrometry. Accuracy of the $\mathrm{Sr}$ isotopic composition was monitored using the NIST SRM987 $\mathrm{Sr}$ isotopic standard. Chemical processing blanks are $<150$ picograms of $\mathrm{Sr}$ and $<200$ picograms $\mathrm{Rb}$, which are insignificant relative to the amount of sample processed. Phlogopite Rb-Sr model ages are calculated using an assumed initial ${ }^{87} \mathrm{Sr} /{ }^{86} \mathrm{Sr}$ ratio of 0.705 (Table 1). Uncertainties for the model age dates are estimated by combining a $\pm 1 \%$ uncertainty in measured $\mathrm{Rb} / \mathrm{Sr}$ with variation in the initial ${ }^{87} \mathrm{Sr} /{ }^{86} \mathrm{Sr}$ ratio between 0.7025 and 0.7075 . For radiogenic phlogopite with ${ }^{87} \mathrm{Rb} /{ }^{86} \mathrm{Sr}>200$, the model age uncertainty is small and is dominated by the analytical uncertainty in $\mathrm{Rb} / \mathrm{Sr}$. For phlogopite with ${ }^{87} \mathrm{Rb} /{ }^{86} \mathrm{Sr}<200$, the model age uncertainty increases and is dominated by the range in assumed initial ${ }^{87} \mathrm{Sr} /{ }^{86} \mathrm{Sr}$.

\section{RESULTS AND DISCUSSION}

\section{COMPARISON WITH PALYNOFLORA AGE DATA}

Palynological taxa date the Giraffe kimberlite at younger than Middle Eocene (about $50 \mathrm{Ma}$; Stasiuk et al., 2000), and the Hawk kimberlite at younger than Paleocene (about $58 \mathrm{Ma}$; Nassichuk and McIntyre, 1995). The Rb-Sr model age obtained for the Giraffe kimberlite is $47.8 \pm 1.4 \mathrm{Ma}$, and that for the Hawk kimberlite is $48.0 \pm 1.3 \mathrm{Ma}$; both are consistent with the palynoflora age constraints.

\section{REPRODUCIBILITY OF EKATI RB-SR MODEL AGES}

Six Ekati kimberlites have been evaluated for reproducibility of $\mathrm{Rb}-\mathrm{Sr}$ model ages over an analysis time period of three years (Table 1), with good results. For example, the Brent kimberlite has yielded two model age determinations of $47.1 \pm 0.9 \mathrm{Ma}$ and $47.7 \pm$ 2.0 Ma and the Beartooth kimberlite has model age determinations of $53.1 \pm 1.0 \mathrm{Ma}$ and $53.0 \pm 1.6 \mathrm{Ma}$. These data suggest that for phlogopite samples with high $\mathrm{Rb} / \mathrm{Sr}$, reproducibility of $\mathrm{Rb}-\mathrm{Sr}$ model ages is no worse than $\sim \pm 0.5 \mathrm{Ma}$.

\section{DISTRIBUTION OF EKATI RB-SR MODEL AGES}

The $\mathrm{Rb}$-Sr model ages range from $\sim 45 \mathrm{Ma}$ (Aaron kimberlite) to $\sim 61 \mathrm{Ma}$ (Rufus and Glory kimberlites). However, the $\mathrm{Rb}-\mathrm{Sr}$ model ages are not uniformly distributed throughout this age range, and three primary 
Table 1: Summary of Rb-Sr Model Ages

$\begin{array}{lcc}\text { Kimberlite } & \text { Model age (Ma) } & \pm(\mathrm{Ma}) \\ \text { Aaron } & 45.2 & 1.3 \\ \text { Brent } & 47.1 & 0.9 \\ \text { Brent } & 47.7 & 2.0 \\ \text { Giraffe } & 47.8 & 1.4 \\ \text { Hawk } & 48.0 & 1.3 \\ & & \\ \text { Leslie } & 52.7 & 2.9 \\ \text { Leslie } & 52.0 & 6.6 \\ \text { Koala N } & 53.3 & 0.9 \\ \text { Falcon } & 51.5 & 1.7 \\ \text { Point Lake } & 51.5 & 0.8 \\ \text { Point Lake } & 51.6 & 0.8 \\ \text { Beartooth } & 53.1 & 1.0 \\ \text { Beartooth } & 53.0 & 1.6 \\ \text { Grizzly } & 50.8 & 4.8 \\ \text { Zach } & 52.8 & 0.8 \\ \text { Bison } & 54.8 & 1.1 \\ \text { Bison } & 54.7 & 0.9 \\ \text { Lynx } & 56.4 & 4.8 \\ \text { Cardinal } & 54.8 & 1.9 \\ & & \\ \text { Shark } & 58.4 & 1.7 \\ \text { Glory } & 61.3 & 3.4 \\ \text { Rooster } & 58.7 & 2.3 \\ \text { Rufus } & 61.1 & 2.1 \\ \text { Crab } & 58.4 & 0.9 \\ \text { Cobra S } & 59.7 & 1.3 \\ \text { Cobra S } & 60.2 & 1.2 \\ \text { Panther } & 58.3 & 5.1 \\ \text { Rattler } & 59.7 & 1.5 \\ \text { Antelope } & 59.5 & \end{array}$

age clusters can be identified at $\sim 47 \mathrm{Ma}, \sim 51-55 \mathrm{Ma}$ and $\sim 58-61 \mathrm{Ma}$ (Table 1, Figure 1). The youngest of these age clusters, comprising the Aaron, Brent, Giraffe and Hawk kimberlites compares favourably in age with the $\mathrm{Rb}$-Sr date for the Mark kimberlite determined by Davis and Kjarsgaard (1997). Our phlogopite Rb-Sr data for Brent, Giraffe and Hawk plot on the Mark Rb$\mathrm{Sr}$ regression (Figure 2). Although there is no a priori reason to include these data together with Mark, for reference only the combined regression yields an identical age of $47.8 \pm 0.3 \mathrm{Ma}$, with no increase scatter about the regression (Model 1, MSWD = 1.3). The Eocene Mark kimberlite is one of the youngest reliably dated Slave province kimberlites, and our data indicate it is not an isolated example of kimberlite activity at that time. The model age of $45.2 \pm 1.3 \mathrm{Ma}$ for the Aaron kimberlite additionally indicates that kimberlite emplacement may extend to ages younger than $\sim 47.5$ Ma.

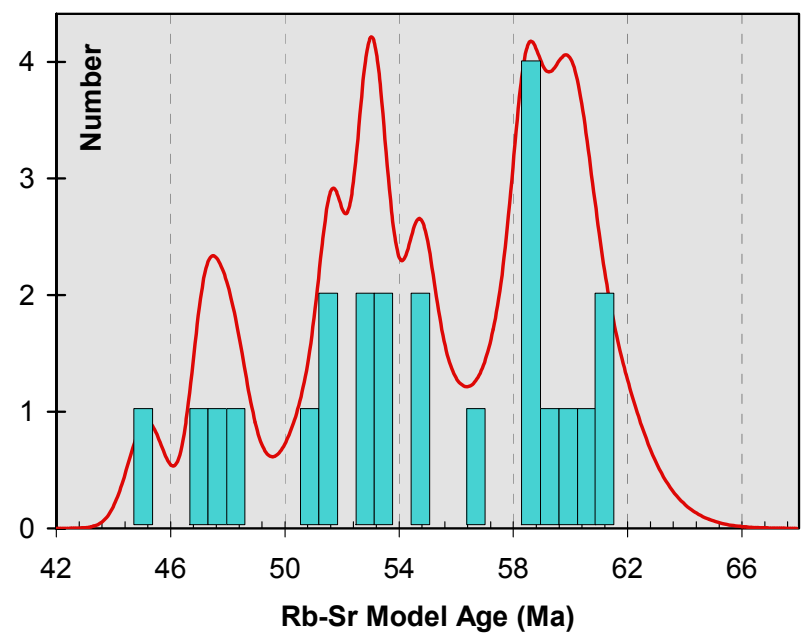

Figure 1: Cumulative probability distribution for $\mathrm{Rb}-\mathrm{Sr}$ phlogopite model ages from 23 Ekati property kimberlites. Duplicated age analyses are not included.

The second age cluster of $\sim 51$ to 55 Ma kimberlites comprises 10 kimberlites, primarily from the central and eastern region of the Ekati property. This sample set contains several high $\mathrm{Rb} / \mathrm{Sr}$ samples that yield model ages clearly different from one another, such as Bison $(54.7 \pm 0.9 \mathrm{Ma})$ and Point Lake $(51.5 \pm 0.8 \mathrm{Ma})$. Model age differences of this magnitude are unlikely to be related to coeval kimberlites having vastly different initial ${ }^{87} \mathrm{Sr} /{ }^{86} \mathrm{Sr}$ ratios, but rather reflect true age

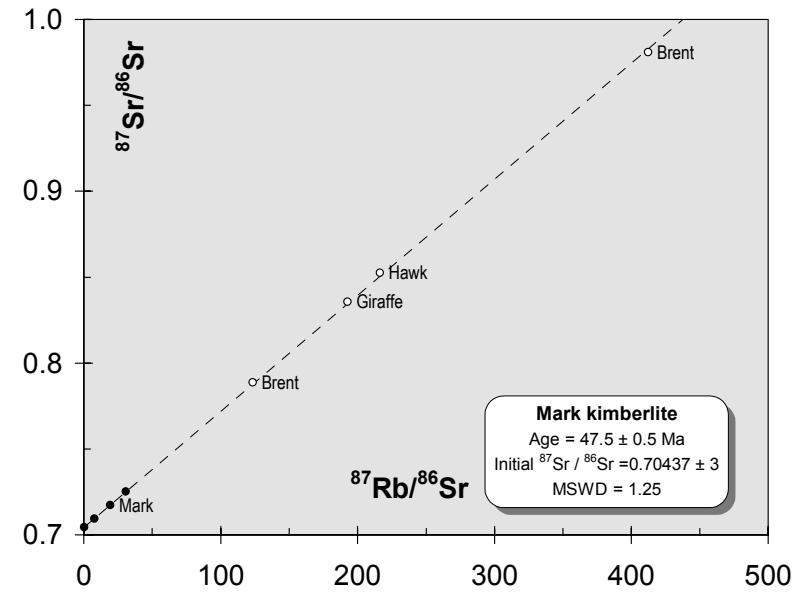

Figure 2: $\mathrm{Rb}-\mathrm{Sr}$ isochron diagram showing phlogopite and whole-rock data for the Mark kimberlite (Davis and Kjarsgaard, 1997), and the regression line fitted to these data yielding an age of $47.5 \pm 0.5 \mathrm{Ma}$. Also shown are four $\mathrm{Rb}-\mathrm{Sr}$ phlogopite analyses from three kimberlites (this study) that fall on the Mark kimberlite regression. 
differences within this group of kimberlites. Of note are three kimberlites, Bison, Lynx and Cardinal that yield model ages of 55-56 Ma, and constitute the oldest members of this cluster of model ages. These samples

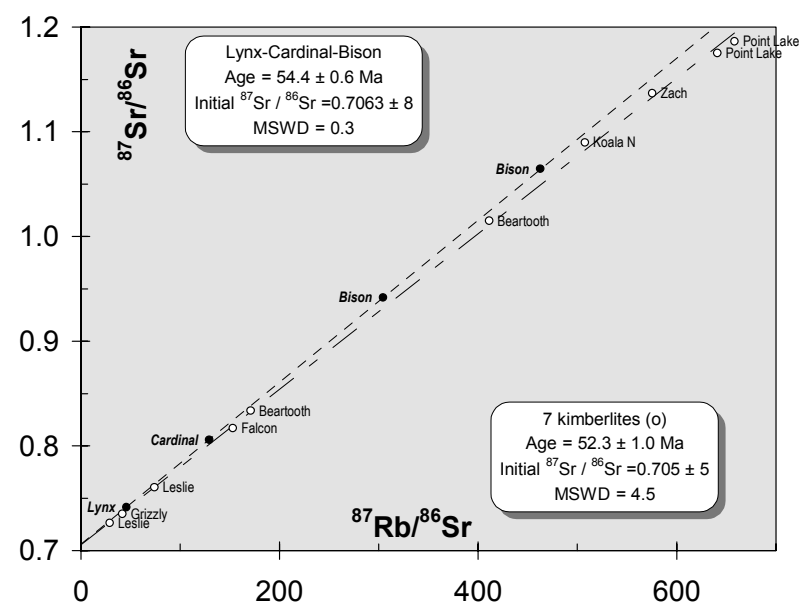

Figure 3: $\mathrm{Rb}-\mathrm{Sr}$ isochron diagram showing $\mathrm{Rb}-\mathrm{Sr}$ phlogopite data from kimberlites of the $\sim 51-55 \mathrm{Ma}$ age cluster. A wellfitted regression from the Lynx-Cardinal-Bison kimberlites yields an age of $54.4 \mathrm{Ma}$, similar to ages determined for kimberlites from the Diavik diamond mine. Seven other kimberlites plot below this regression, and are interpreted to record a span of emplacement ages to $\sim 51 \mathrm{Ma}$.

define a well-fitted regression yielding an age of $54.4 \pm$ $0.6 \mathrm{Ma}$ (Model 1, MSWD = 0.3; Figure 3), which we show for reference. The age of $54.4 \pm 0.6 \mathrm{Ma}$ indicated for the Lynx, Bison and Cardinal kimberlites is similar to $\mathrm{Rb}-\mathrm{Sr}$ ages determined for kimberlites from the Diavik Diamond Mine, bordering the Ekati property's southern boundary $(54.8 \pm 0.3$ to $56.0 \pm 0.7 \mathrm{Ma}$; Graham et al., 1999; Heaman et al., 2003).

The remaining analyses of seven kimberlite samples plot below this reference regression, and scatter about a reference regression line having an age of $52.3 \pm 1.0$ Ma (Model 3, MSWD = 4.5). The scatter of the analyses around the regression line is greater than known analytical uncertainties, and likely relates to small but real differences in emplacement ages between the samples, over the time period of $54-51 \mathrm{Ma}$. Ekati kimberlites currently known to have the highest economic diamond potential belong to this age cluster, and at a local scale some of these kimberlites show a NNE structural emplacement trend.

The third Rb-Sr model age cluster occurs at $\sim 58-61$ $\mathrm{Ma}$ and comprises nine kimberlites distributed throughout the Ekati property. Unlike samples within the $\sim 51-55 \mathrm{Ma}$ age cluster, none of the individual model ages in the $\sim 58-61$ Ma age cluster can be distinguished from another within the assigned

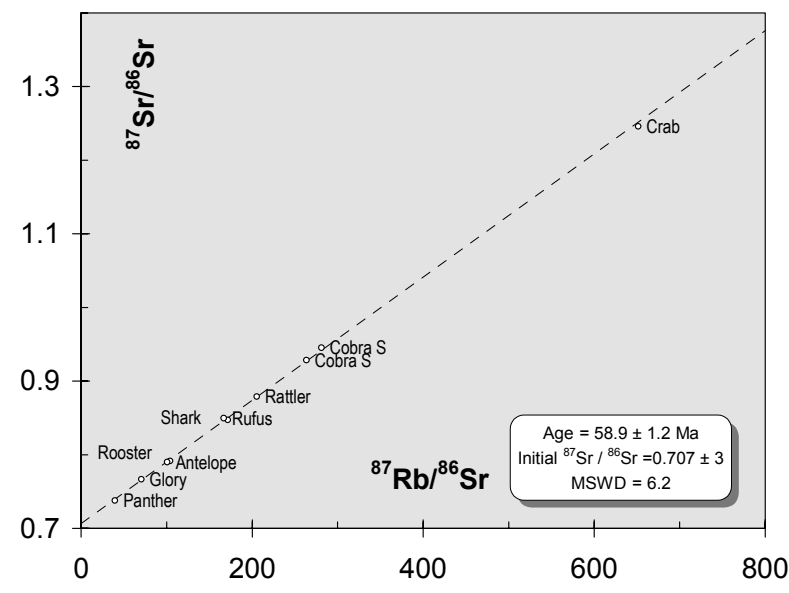

Figure 4: $\mathrm{Rb}-\mathrm{Sr}$ isochron diagram showing $\mathrm{Rb}-\mathrm{Sr}$ phlogopite data from kimberlites of the $\sim 59-61$ Ma age cluster.

uncertainty estimates (Table 1). These data are presented in Figure 4, and as a group yield a reference regression having an age of $58.9 \pm 1.2 \mathrm{Ma}$ (Model 3, MSWD = 6.2).

\section{CONCLUSION}

The model-age relations reported herein demonstrate that $\mathrm{Rb} / \mathrm{Sr}$ data for macrocrystal phlogopite from kimberlite may be used to good effect to define and interpret multiple intrusive episodes, particularly when viewed in the context provided by independently determined $\mathrm{Rb}-\mathrm{Sr}$ isochrons. Three clear intrusive episodes can be isolated for phlogopite-bearing kimberlites in the Ekati province, but the current available data suggest that two further episodes may be defined with further investigation. 


\section{REFERENCES}

Davis, W.J., Kjarsgaard, B.A., 1997. A Rb-Sr isochron age for a kimberlite from the recently discovered Lac de Gras field, Slave province, northwest Canada. J. Geol. 105: 503-509.

Graham, I., Burgess, J.L., Bryan, D., Ravenscroft, P.J., Thomas, E., Doyle, B.J., Hopkings, R., and Armstrong, K.A., 1999. Exploration history and geology of the Diavik kimberlites, Lac de Gras, Northwest Territories, Canada. Seventh International Kimberlite Conference 1, 262-279.

Heaman, L.M., Kjarsgaard, B.A., and Creaser, R.A., 2003. The Timing of Kimberlite Magmatism in North America: Implications for Global Kimberlite Genesis and Diamond Exploration. Lithos, in press.

Nassichuk, W.W., and McIntyre, D.J., 1995. Cretaceous and Tertiary fossils discovered in kimberlites at Lac de Gras in the Slave province, Northwest Territories. In: Current Research 1995-B; Geological Survey of Canada, p. 109-114.

Stasiuk, L.D., Sweet, A.R., Snowdon, LR., Hamblin, T., and Nassichuk, W., 2000, Preliminary sedimentology, organic petrology, organic geochemistry and palynology of sediments from Giraffe pipe, Lac de Gras region, NWT. Unpublished report.

Contact: RA Creaser, University of Alberta, 126ESB,

Edmonton, Canada, T6G 2E3, E-mail:

robert.creaser@ualberta.ca 